Freeman, M. (2017) 'Interactive and participatory worlds', in Wolf, M. J. P., ed. The Routledge companion to imaginary worlds. New York: Routledge, pp. 198-206.

This is an Accepted Manuscript of a book chapter published by Routledge in 'The Routledge companion to imaginary worlds' on 04/10/2017 available online at: https://www.routledge.com/The-RoutledgeCompanion-to-Imaginary-Worlds/Wolf/p/book/9781138638914

\title{
ResearchSPAce
}

\author{
http://researchspace.bathspa.ac.uk/
}

This pre-published version is made available in accordance with publisher policies.

Please cite only the published version using the reference above.

Your access and use of this document is based on your acceptance of the ResearchSPAce Metadata and Data Policies, as well as applicable law:https://researchspace.bathspa.ac.uk/policies.html

Unless you accept the terms of these Policies in full, you do not have permission to download this document.

This cover sheet may not be removed from the document.

Please scroll down to view the document. 


\title{
Interactive and Participatory Worlds
}

\section{Matthew Freeman}

\begin{abstract}
This chapter explores some of the pertinent issues surrounding interactive and participatory worlds, both in and outside of the context of media convergence and participatory culture. Exploring the cultural, creative and interactive components of a range of participatory worlds, the chapter outlines the historical contexts by which audiences began to interact with imaginary worlds during the early part of the twentieth century, before examining the dynamics of participatory worlds in the age of digital convergence. Finally, the chapter offers new perspectives on participatory and interactive worlds by considering the underlying rationales that can underpin why audiences choose to participate in storyworlds across media.
\end{abstract}

\section{Author Biography}

Dr Matthew Freeman is Senior Lecturer in Media and Communication at Bath Spa University, and Director of its Media Convergence Research Centre. He is the author of Historicising Transmedia Storytelling: Early Twentieth-Century Transmedia Story Worlds (Routledge, 2016), the author of Industrial Approaches to Media: A Methodological Gateway to Industry Studies (Palgrave Macmillan, 2016), and the co-author of Transmedia Archaeology: Storytelling in the Borderlines of Science Fiction, Comics and Pulp Magazines (Palgrave Pivot, 2014). His research examines cultures of production across the borders of media and history, and he has published in journals such as The International Journal of Cultural Studies, the Historical Journal of Film, Radio and Television, and the International Journal of Communication. 


\section{Interactive and Participatory Worlds}

\section{Matthew Freeman}

Interactive and participatory worlds are in many defining ways products of a wider culture and technological landscape that, as Henry Jenkins puts it, "absorbs and responds to the explosion of new media technologies that make it possible for average consumers to archive, annotate, appropriate, and recirculate media content in powerful new ways" (1992, p. 55).

This chapter explores some of the pertinent issues surrounding interactive and participatory worlds, both in and outside of the wider context of media convergence and participatory culture. I detail the defining characteristics of a range of participatory worlds, exploring their cultural, creative and interactive components. To do so, the chapter outlines the social and historical contexts by which audiences began to interact with imaginary worlds during the early part of the twentieth century, before moving on to examine the various dynamics of participatory worlds in the age of digital convergence. Finally, the chapter offers some new perspectives on participatory and interactive worlds by considering the complex underlying rationales that can underpin why audiences choose to participate in storyworlds across media.

\section{Contextualising Interactive and Participatory Worlds}

The practice of producing and engaging with imaginary storyworlds that are interactive or participatory in nature can be understood in a number of ways. It can also be traced and conceptualised according to a range of contexts and perspectives. Famously, Henry Jenkins defined participatory culture as "culture in which and other consumers are invited to actively participate in the creation and circulation of new content" (2006, p. 331). According to Jenkins, participatory culture is characterised by particular ideals such as a "strong support for creating and sharing one's creations with others", where "members believe that their 
contributions matter" and where "members feel some degree of social connection with one another (at the least they care what other people think about what they have created)" (2012).

Jenkins, moreover, theorised the relationships between participatory culture and media convergence as to some extent intertwined developments of the contemporary landscape. Media convergence, itself "the coming together of things that were previously separate" (Meikle and Young, 2012, p. 2), has come to dominate contemporary understandings of the models through which culture is produced and consumed across platforms. Entire media industries, along with their technologies and practices, have become increasingly aligned, branded, participatory and networked. As Henry Jenkins writes, "media convergence makes the flow of content across multiple media inevitable" (2003). Convergence has accelerated the ways in which imaginary worlds are developed as media-traversing participatory spaces.

It is in this way that concepts of media convergence, participatory culture and transmediality have become key to exploring the interactivity and participation of imaginary worlds. Mark J. P. Wolf shows that "imaginary worlds are not only transmedial and transnarrative, but transauthorial as well" (2012, p. 269). That is to say that imaginary worlds often traverse multiple media platforms as well as authors in the process of building a rich canvas of fictional characters, spaces, places, religions, myths, politics, etc. World-making, then, itself the art of transmedia storytelling, argues Jenkins, is "the process of designing a fictional universe that will sustain ... development, one that is sufficiently detailed to enable many different stories to emerge but coherent enough so that each story feels like it fits with the others" (2006, p. 335). In other words, transmediality has become a means of understanding the flow of content and imaginary storyworlds across multiple media, with this "circulation 
of media content - across different media systems, competing media economies, and national borders - depend[ing] heavily on consumers' active participation" (Jenkins, 2006, p. 3).

Though convergence, as Stein notes, "recognizes the expanse of audience authorship", this participation of audiences is most notably - though not always - an affordance of digital media specifically rather than a general characteristic of transmediality itself (2013, p. 405). Interactivity is a property of technology, while participation is a property of culture. Jenkins (2009) insists that the performance of audiences is often a key outcome of transmedia storytelling, describing "the ability of transmedia extensions to lead to fan produced performances than can become part of the transmedia narrative itself." Scolari, Bertetti and Freeman $(2014$, p. 3) suggest that there are different levels of participation and performance ranging from the consumer of a single media form to the "prosumer" who expands the storyworld by producing new content, typically via interactive digital media forms such as websites and online platforms including YouTube. Jenkins emphasises that transmediality, new technologies and convergence have indeed all worked to make this kind of performance possible, empowering audiences by giving them the "right to participate" (2006, p. 23).

\section{The Past}

That right to participate may be true, but participatory and interactive worlds are by no means specific to the digital age. Steve Coulson, Creative Director of Campfire - a Toronto-based company specialising in participatory storytelling - argues that media-based participation can be stripped to a few basic characteristics, most of which predate contemporary convergences:

At a very simple level, you can say participation is playing a game, or doing something interactive on a screen. But at its most simplistic level, participation may 
be in what order to consume media, or when to consume them, and how fast to consume them (Hassler-Forest, 2016b, p. 685).

Nearly a hundred years before the turn of the digital age, indeed, The Wonderful Wizard of $O z$ from 1900 was extending its own story across multiple media and inviting consumers to interact with its narrative adventures. That tale's magical Land of Oz storyworld was crossing novels, posters, theatre, newspaper comic strips and cinema by around 1910, inviting audiences to interact with the world. With regards to the Land of Oz, competitions became a notable strategy for building the world as an interactive space at this time competitions that were woven into the stories of a comic strip series called Queer Visitors from the Marvelous Land of $\mathrm{Oz}$, published in 1904. Its author, L. Frank Baum, used competitions as a means of exploiting his fictional characters and inviting participation working to point audiences towards $\mathrm{Oz}$ merchandise, which in doing so led to new fictional settings being added to the storyworld. Consider "What Did the Woggle-Bug Say?", a popular competition used in the Queer Visitors comic strips and which built a weekly contest around the Woggle-Bug character in the first seventeen editions. Throughout the course of each comic, the Woggle-Bug was posed a question from his fellow Oz comrades, though his answer was not revealed to readers. At the end of each story, readers were then asked 'What did the Woggle-Bug say?' and were invited to submit their guesses to the newspaper in the hope of winning items of $\mathrm{Oz}$ merchandise and cash prizes. But these responses did more than promote merchandise; they also dictated the storytelling direction of upcoming comic strips, as the often highly creative and imaginative ideas of readers came to influence and inspire Baum to explore further untapped terrains of the already expanding Land of Oz storyworld. 
Such a case of competitions and storytelling aligning shows how early twentieth-century newspaper comic strips came to exemplify features of participatory and interactive worldbuilding, while the competitions published inside those newspapers also provide us with an historical example of how "fan produced performances ... invited by the creator ... become part of the transmedia narrative itself" manifested at this particular time (Jenkins, 2009). The case of Oz persuasively demonstrates that audience explorations of imaginary worlds significantly pre-date the contemporary era of convergence and participatory culture.

Similarly, both Will Brooker (2002) and Jonathan Gray (2010) have shown how toys can expand or reshape a participatory transmedia world, and in the 1930s cases such as Tarzan can be seen to have adopted strategies of merchandising to enable the stories and storyworld to extend and expand through participation. By this point Tarzan's creator Edgar Rice Burroughs had issued a total of twenty-six companies with a license to manufacture Tarzan merchandise (Porges, 1975, pp. 489-492). Items made in the likeness of Tarzan or branded items which that character used in the context of the storyworld included Tarzan bread, Tarzan knives, Tarzan belts, Tarzan household kitchen utensils and Tarzan ornamental bows and arrows, to name just a few (Vernon, 2008, pp. 34-35). This merchandise, carefully inserted into the fictional milieu of the stories - which themselves were expansions of the storyworld published elsewhere - was an intertextual cornerstone of the fictional storyworld that impacted on how the narrative actually unfolded across media. (Entire plots in the Tarzan comic strip, for example, were dictated by Burroughs' merchandising deals (Freeman, 2016)). And in so doing, it was the merchandise - functioning as artefacts within the world itself and as a physical, extractable item from that world - contributed as much to the process of building the Tarzan storyworld as any of the media forms in which its stories unfolded. 


\section{The Present}

In the past, in fact, interactive and participatory worlds were largely underpinned by widescale industrial and technological developments, notably in mass communication, new printing technologies and merchandising, all of which afforded audiences to more easily engage with the media creations that they loved. Understanding how participatory worlds existed under a different logic besides the digital participatory model of contemporary media convergences also means acknowledging factors of promotion, with participation offered as a kind of marketing strategy (Freeman, 2016). It is this same notion of participation-aspromotion that has come to characterise any number of interactive and participatory worlds in the digital era, too. In the age of convergence culture, the job of continuing to expand the Land of $\mathrm{Oz}$, for example, across media rests most emphatically in the hands of marketing teams and digital agencies. One website called findyourwaytooz.com, created by Disney and UNIT9 and devised as an official promotional website for Oz the Great and Powerful (2013), allowed audiences to walk around the fictional spaces seen throughout the narrative of that film. The website made use of digital convergence by blending 3D animation, video, audio and gameplay to take audiences on an 'interactive journey through a Kansas circus, which leads you to the Land of Oz after you are swept up by a massive storm' (UNIT9, 2013).

Transmedia websites such as findyourwaytooz.com are typically prized for their ability to blend the affordances of multiple media forms to create, in that instance, at least, "a fun, immersive experience that users can form a strong connection with" (UNIT9, 2013). Steve Coulson, despite his earlier characterisation of participatory worlds based on traits of play, order and speed of consumption, similarly notes that the on-demand nature of digital media is key to understanding the allure of many contemporary interactive and participatory worlds (Hassler-Forest, 2016b). For Coulson, on-demand affords audiences to "choose when, where, 
and what comes to [them] and in which format, and certainly digitization is therefore a big part of the on-demand revolution" (Hassler-Forest, 2016b, p. 685). In the digital industry, too - at least in the US and the UK - participatory transmedia worlds based on the modern ondemand nature of digital convergences have themselves come to be perceived as a new form of storytelling or narrative engagement. Conducttr, for example, a London-based transmedia content producer, works to generate the building of participatory storyworlds via forms such as alternate reality games (ARG) or location-based games (Pratten, 2012). Conducttr works on the assumption that a story allowing audiences to roam the world and discover the story for themselves by questioning, unlocking, solving, visiting and generally exploring all the platforms made available by the creators is a richer, more dynamic and engaging story.

Yet a model of participatory transmedia worlds based on this logic of convergence culture faces notable challenges. One challenge concerns the question mark over how to produce (or rather co-produce) such participatory transmedia worlds outside of ARG or promotion-based strategies. Jonathan Gray, for instance, explores the benches that were erected in anticipation of the film District 9 (2009), and the ways they contributed to narrative exposition and shaped emotional reactions to the film as key sites of participatory world-building (2010b):

All that can happen before you even know there is a movie. Now when you are told that there is a movie, and that these benches are part of it, they have given you an experience of that world. You have set foot in it and had an experience in it (Gray, 2010b).

Like many of today's participatory storyworlds based in the film and television industries, at least, much of this interactive and participatory content occupies the status of promotion or 
publicity. Brian Clark notes that most of the transmedia projects based in the US and UK today are funded through promotional and marketing funds (2011). Clark goes on to note that the creatives involved in such so-called marketing materials continue to make a forceful argument that their work should be understood as "content" and not simply as "promotion", with economic and labour relations issues at stake in the dispute between the two terms.

A second challenge concerning a contemporary model of participatory transmedia worlds concerns a question mark over why, or when, audiences choose to participate in worlds. Indeed, what exactly is the relationship between what Michael Saler calls "geographies of the imagination" (2012, p. 4) and the audiences who actually engage with them? Christy Dena introduces an emerging form of participatory culture, "one that is not a modification or elaboration of a primary producer's content", but instead one that is based on a theory of "tiering" audiences in ARGs, "targeting different players with different content" (2008, p. 2).

Just as Dena explores aspects of player-created tiers to assess shifts in participatory ARGs, Charlotte Taylor-Ashfield shows how authorship standards across film, television and comics industries can impact on how audiences engage with interactive and participatory worlds, and what they do with those worlds (2016). Importantly, Taylor-Ashfield points to the ways in which fans of Captain Marvel attached themselves closely to the work of author Kelly Sue DeConnick, which resulted in containing transmedia migration and participation rather than cultivating its spread, thus effectively regulating the participation of audiences (2016).

\section{The Future?}

Moreover, amidst the influx of content, brands, narratives and indeed worlds across multiple platforms that have flourished with the rise of media convergence, it is not enough to assume 
that the creation of a single and coherent fictional storyworld is necessarily enough to explain the specificities and reasons for why audiences choose (or in some cases, choose not) to cross multiple media and to participate in the world. Hassler-Forest (2016a, p. 3) argues that there is a fundamental contradiction between industrial understandings of a fictional transmedia storyworld, which tend to emphasise "straightforward assembly" and "creative production", and "fan culture perspectives", which highlight expansiveness and the creative deferment of narrative closure. Further to this, do all audiences really engage in participatory transmedia activities? Are worlds in and of themselves powerful enough to encourage fans to follow fictions across an array of texts? And is the creation of an interconnected world capable of igniting sustained participation from all corners of a given fan base? If not, then which fans do opt to engage in participatory practices, under what circumstances, and for what reasons?

Given the multifaceted and seemingly endless combination of ways that mark the actions of today's media audiences, perhaps it is time to move beyond characterising the behaviours of participatory audiences simply according to more industrially defined concepts of storytelling, world-building, brand or character. Rather, it is crucial to analyse the behaviours and motivations of a participatory media-crossing audience according to a much more fluid, paratextual and value-laden participatory ethos. At a moment when the media industries are producing so much content, across so many platforms, each with so many varying extensions, it is now time to re-think critical assumptions that it is simply a narrative, storyworld or even a character that is being engaged with across platforms, and instead to analyse the more specific and messy rationales for why audiences participate in storyworlds across media.

Moving towards a fan studies perspectives and, in particular, building on Matt Hills' work into how transmedia fandoms operate as unique "communities of practice" (2015), consider 
how fans of the aforementioned Captain Marvel engaged in participatory and interactive practices only when the participatory behaviours in question encapsulated a layered ethos based on an anti-commercial gift economy - that is, participatory fan productions that are circulated freely with no financial gain for contributors, all the while held up by an underlying sense of reciprocity between fans (Hellekson, 2009). Media industries have frequently interpreted the ideal form of fan participation as 'continuous consumption' and financial support of a franchise (Scott, 2012, p. 43), which for a corporation such as Marvel would be enacted by fans through collecting trivia, merchandise, and indeed comic books themselves. Even prior to the first issue of the Captain Marvel comic book being published, writer DeConnick was also using "fannish" platforms including Tumblr and Pinterest to circulate less commercial forms such as fan art, crafts and cosplay of the character. This meant that prior to any official texts being published, DeConnick - positioned by many fans as the 'auteur' of this fandom (Taylor-Ashfield, 2016) - was acknowledging transformative works as not only a valid way to participate within the fan community, but also legitimising this interactive, freely circulated material as valuable participatory extensions of the Captain Marvel imaginary world. DeConnick even participated in this fan world herself, selling Tshirts through WeLoveFine and donating her profit to The Girls Leadership Institute - a charity whose goal to 'help foster and give voice to the heroines of tomorrow' aligns closely with the gift economy values of the Captain Marvel fan community (Taylor-Ashfield, 2016).

In the case of the participatory motivations of the Captain Marvel fan community, at least, reciprocity, community, anti-commercialism - not to mention an open dialogue between creator and consumer - all directly informed which stories fans chose to engage with and how they chose to participate in the world of those stories. In some sense, then, the fan practices of participating in the imaginary worlds of twenty-first century popular culture are 
in part based broadly on the sharing of personal values within, across and between media philosophising, not just interacting with, imaginary worlds across multiple platforms.

Importantly, this form of world participation based on fan-made crafts, fan-fiction and fan-art exemplifies the kind of participatory culture first envisaged by Jenkins in Textual Poachers (1992), and then realised more recently in a more socio-political sense in By Any Media Necessary (2016). In the latter book, Jenkins, Shresthova, Gamber-Thompson, KlingerVilenchik and Zimmerman explore the complexities and the challenges faced by the current youth generation seeking to acquire "the skills necessary for political participation at an age where there is less than complete access to the rights of citizenship" (2016, p. 7). So far, the academic study of imaginary worlds has not done enough to conceptualise the specificities and peculiarities of how and why audiences choose - or choose not - to interact with and to participate in imaginary worlds. As researchers of imaginary worlds, we should pay more attention to such specificities and peculiarities, for the politics of individual participation raise important questions about how and why imaginary worlds continue to be built. 


\section{References}

Brooker, W. (2002) Using the Force: Creativity, Community and Star Wars Fans. London: Bloomsbury.

Brooker, W. (2013) Batman Unmasked: Analysing a Cultural Icon, New York: Continuum.

Clark, B. (2011) Brian Clark on Transmedia Business Models (Part Two). Retrieved 30 August 2014.<http://henryjenkins.org/2011/11/brian_clarke_on_transmedia_bus.html>

Dena, C. (2008) Emerging Participatory Culture Practices: Player-Created Tiers in Alternate Reality Games, Convergence: The International Journal of Research into New Media Technologies, 14(1), 41-57.

Evans, E. (2011) Transmedia Television: Audiences, New Media, and Daily Life. New York and London: Routledge.

Evans, E. (2015) Building Digital Estates: Transmedia Television in Industry and Daily Life. Paper presented at the ECREA TV in the Age of Transnationalisation and Transmediation Conference, Roehampton University (June 22).

Fast, K. and Örnebring, H. (2015) Transmedia world-building: The Shadow (1931present) and Transformers (1984-present), The International Journal of Cultural Studies, doi: $10.1177 / 1367877915605887$. 
Freeman, M. (2014) Advertising the Yellow Brick Road: Historicizing the Industrial Emergence of Transmedia Storytelling, International Journal of Communication, 8, 23622381.

Freeman, M. (2016) Historicising Transmedia Storytelling: Early Twentieth-Century Transmedia Story Worlds. London and New York: Routledge.

Gray, J. (2010a) Show Sold Separately: Promos, Spoilers, and Other Media Paratexts. New York: New York University Press.

Gray, J. (2010b) On Anti-Fans and Paratexts: An Interview with Jonathan Gray (Part Two). Retrieved June 4, 2016. <http://henryjenkins.org/2010/03/on_antifans_and_paratexts_an_1.html>

Harvey, C. B. (2015) Fantastic Transmedia: Narrative, Play and Memory Across Science Fiction and Fantasy Storyworlds. Basingstoke: Palgrave MacMillan.

Hassler-Forest, D. (2016a) Science Fiction, Fantasy, and Politics: Transmedia WorldBuilding Beyond Capitalism. Maryland: Rowman \& Littlefield.

Hassler-Forest, D. (2016b) Skimmers, Dippers, and Divers: Campfire's Steve Coulson on Transmedia Marketing and Audience Participation, Participations: Journal of Audience \& Reception Studies, 31(1), 682-692.

Hay, J. and Couldry, N. (2011) Rethinking Convergence/Culture: An Introduction, Cultural Studies 25(4), 473-486. 
Hellekson, K. (2009) A Fannish Field of Value: Online Fan Gift Culture, Society for Cinema \& Media Studies, 48(4), 113-118.

Hills, M. (2015) The Expertise of Digital Fandom as a "Community of Practice": Exploring the Narrative Universe of Doctor Who, Convergence: The International Journal of Research into New Media Technologies, 21(3), 360-374.

Holt, J. and Sanson, K. (eds.) (2014) Connected Viewing: Selling, Streaming and Sharing Media in the Digital Age. London and New York: Routledge.

Jenkins, H. (1992) Textual Poachers: Television Fans and Participatory Culture. London and New York: Routledge.

Jenkins, H. (2003) Transmedia Storytelling. Retrieved 4 February 2013.

<http://www.technologyreview.com/news/401760/transmedia-storytelling/>

Jenkins, H. (2006) Convergence Culture: Where Old and New Media Collide. New York University Press.

Jenkins, H. (2007) Transmedia Storytelling 101. Retrieved 30 September 2011. <http://henryjenkins.org/2007/03/transmedia_storytelling_101.html> Jenkins, H. (2009) The Revenge of the Origami Unicorn: Seven Principles of 
Transmedia Storytelling. Retrieved 20 February 2012.

<http://henryjenkins.org/2009/12/the_revenge_of_the_origami_uni.html>

Jenkins, H. (2011) Transmedia 202: Further Reflections. Retrieved May 6, 2014, from <http://henryjenkins.org/2011/08/defining_transmedia_further_re.html>

Jenkins, H. (2012) Participatory Culture: What Questions Do YOU Have? Retrieved May 6, 2014. <http://henryjenkins.org/2012/08/participatory-culture-what-questions-do-youhave.html>

Jenkins, H. (2016a) Confronting the Challenges of Participatory Culture: Media Education for the 21st Century (Part One). Retrieved November 30, 2016.

<http://henryjenkins.org/2006/10/confronting_the_challenges_of.html>

Jenkins, H. (2016b) Confronting the Challenges of Participatory Culture: Media Education for the 21st Century (Part Two). Retrieved November 30, 2016.

<http://henryjenkins.org/2006/10/confronting_the_challenges_of_1.html>

Jenkins, H., Shresthova, S., Gamber-Thompson, L., Klinger-Vilenchik, N. \& Zimmerman, A. M. (2016) By Any Media Necessary: The New Youth Activism. New York: New York University Press.

Johnson, D. (2013) Media Franchising: Creative License and Collaboration in the Culture Industries. New York: New York University Press. 
Johnston, K. M. (2014) Has Britain Got Transmedia Talent?. Retrieved 24 May 2014. <http://cstonline.tv/has-britain-got-transmedia-talent>

Mann, D. (ed.) (2014) Wired TV: Laboring Over an Interactive Future. New Jersey: Rutgers University Press.

Meikle, G \& Young, S. (2012) Media Convergence: Networked Digital Media in Everyday Life. Basingstoke: Palgrave Macmillan.

Porges, I. (1975) Edgar Rice Burroughs: The Man Who Created Tarzan. Utah: Brigham Young University Press.

Pratten, R. (2012) Writing \& Documenting Open Storyworlds and Participatory Stories. Retrieved December 1, 2016. <http://www.tstoryteller.com/writing-documenting-openstoryworlds-and-participatory-stories>

Saler, M. (2012) As If: Modern Enchantments and the Literary Prehistory of Virtual Reality. Oxford: Oxford University Press.

Scolari, C. A. (2009) Transmedia Storytelling: Implicit Consumers, Narrative Worlds, and Branding in Contemporary Media Production. International Journal of Communication, 3, 586-606.

Scolari, C., Bertetti, P. \& Freeman, M. (2014) Transmedia Archaeology: Storytelling in the Borderlines of Science Fiction, Comics and Pulp Magazines. Basingstoke: Palgrave Pivot. 
Scott, S. (2012) Who's Steering the Mothership?: The Role of the Fanboy Auteur in Transmedia Storytelling. In A. Delwiche and J. Jacobs Henderson (Ed.), The Routledge Handbook on Participatory Culture, (pp.43-52). London and New York: Routledge.

Stein, L. E. (2013) \#Bowdown to Your New God: Misha Collins and Decentered Authorship in the Digital Age. In J. Gray and D. Johnson (Ed.), A Companion to Media Authorship, (pp. 403-425). Oxford: John Wiley \& Sons, Inc.

Stein, L. E. (2015) Millennial Fandom: Television Audiences in the Transmedia Age. Iowa: University of Iowa Press.

Taylor-Ashfield, C. (2016) \#CarolCorps: Interrogating the Utopic Potential of Transmedia Storytelling for Female Superhero Fans. Paper presented at Console-ing Passions: An International Conference on Television, Video, Audio, New Media and Feminism, University of Notre Dame (June 17).

UNIT9. (2013) Case Study: Find Your Way To Oz. Retrieved 14 June 2016. <http://www.html5rocks.com/en/tutorials/casestudies/oz/> Vernon, A. (2008) On Tarzan. London: The University of Georgia Press. Wolf, M. J. P. Building Imaginary Worlds: The Theory and History of Subcreation. London and New York: Routledge. 